\title{
Photodynamic inactivation of recombinant bioluminescent Escherichia coli by cationic porphyrins under artificial and solar irradiation
}

\author{
Eliana Alves • Carla M. B. Carvalho • João P. C. Tomé • Maria A. F. Faustino • \\ Maria G. P. M. S. Neves • Augusto C. Tomé · José A. S. Cavaleiro • Ângela Cunha • \\ Sónia Mendo $\cdot$ Adelaide Almeida
}

Received: 18 March 2008 / Accepted: 30 July 2008 / Published online: 20 August 2008

(C) Society for Industrial Microbiology 2008

\begin{abstract}
A faster and simpler method to monitor the photoinactivation process of Escherichia coli involving the use of recombinant bioluminescent bacteria is described here. Escherichia coli cells were transformed with luxCD$A B E$ genes from the marine bioluminescent bacterium Vibrio fischeri and the recombinant bioluminescent indicator strain was used to assess, in real time, the effect of three cationic meso-substituted porphyrin derivatives on their metabolic activity, under artificial $\left(40 \mathrm{~W} \mathrm{~m}^{-2}\right)$ and solar irradiation $\left(\approx 620 \mathrm{~W} \mathrm{~m}^{-2}\right)$. The photoinactivation of bioluminescent $E$. coli is effective ( $>4 \log$ bioluminescence decrease) with the three porphyrins used, the tricationic porphyrin $\mathrm{Tri}^{-} \mathrm{Py}^{+}-\mathrm{Me}-\mathrm{PF}$ being the most efficient compound. The photoinactivation process is efficient both with solar and artificial light, for the three porphyrins tested. The results show that bioluminescence analysis is an efficient and sensitive approach being, in addition, more affordable, faster, cheaper and much less laborious than conventional methods. This approach can be used as a screening method for bacterial photoinactivation studies in vitro and also for the monitoring of the efficiency of novel photosensitizer
\end{abstract}

E. Alves · C. M. B. Carvalho $\cdot$ Â. Cunha

S. Mendo $\cdot$ A. Almeida $(\square)$

Department of Biology, CESAM, University of Aveiro, 3810-193 Aveiro, Portugal

e-mail: aalmeida@ua.pt

E. Alves

School of Health Technology,

Porto Polytechnic Institute, 4200-465 Porto, Portugal

C. M. B. Carvalho - J. P. C. Tomé · M. A. F. Faustino ·

M. G. P. M. S. Neves · A. C. Tomé · J. A. S. Cavaleiro

Department of Chemistry, QOPNA,

University of Aveiro, 3810-193 Aveiro, Portugal molecules. As far as we know, this is the first study involving the use of bioluminescent bacteria to monitor the antibacterial activity of porphyrins under environmental conditions.

Keywords Cationic porphyrins - Photodynamic antimicrobial therapy $\cdot$ Bioluminescence Escherichia coli . Solar irradiation

\section{Introduction}

The growing reduction of water resources due to environmental pollution has become a major public health concern. Thus, wastewater treatment and disinfection is even more necessary at large scale. The inactivation of pathogenic microorganisms, in the last stage of wastewater treatment, can be achieved by several techniques such as chlorination, ozonation and ultraviolet radiation. To overcome the high costs and the difficulty in implementing these techniques, alternative physico-chemical methods have been studied, namely the photodynamic antimicrobial therapies [1-3]. This somewhat new technique uses a light source (sunlight or artificial light), an oxidizing agent (molecular oxygen dissolved in water) and an intermediary agent [named photosensitizer (PS)], able to absorb and transfer the energy of the light source to molecular oxygen leading to the formation of highly cytotoxic reactive oxygen species $\left({ }^{1} \mathrm{O}_{2}, \mathrm{OH}^{*}\right.$, $\mathrm{O}_{2}^{-}, \mathrm{H}_{2} \mathrm{O}_{2}$ ) [4]. Such species are able to irreversibly alter the cells' vital constituents resulting in oxidative lethal damage [5]. The potential use of this approach for water disinfection has already been studied, showing that photoinactivation (PI) of bacteria in drinking [3] and residual waters $[1,6]$ is possible under artificial or solar irradiation. In those studies, different experimental conditions, namely 
the light source and fluence rate were used. Also, several microorganisms and the PS (methylene blue, Rose Bengal and porphyrins) were tested [3,7]. The results were promising, namely with porphyrins. Porphyrins can be transformed into cationic entities through the insertion of positively charged substituents in the peripheral mesopositions of the tetrapyrrole macrocycle which may largely affect the kinetics and extent of binding to microbial cells [8]. Cationic meso-substituted porphyrins are known to efficiently destroy Gram-negative and Gram-positive bacteria [9-14]. The combination of hydrophobic and hydrophilic substituents in the PS structure results in an intramolecular polarity axis, which can facilitate membrane penetration and produce a better accumulation in subcellular compartments, enhancing the effective photosensitization [15].

To monitor the bacterial PI process, faster methods are required instead of the laborious conventional methods of plating, overnight incubation and time-consuming counting of colony-forming units (CFU) [16, 17]. New approaches to study potential PS in vitro are essential to accelerate the development of photodynamic antimicrobial therapy in drinking and residual water treatment. To this end, the bacterial bioluminescence method, when applied in others areas, is considered to be a rapid [18], sensitive [19] and cost-effective option [17]. It also allows only living or viable cells to be detected and does not need exogenous administration of substrates [20] to obtain light emission. Bioluminescence refers to the process of visible light emission by living organisms [21] and this emission is directly dependent on the metabolic activity of the organism [17]. In that way, the inhibition of cellular activity results in a decrease of the bioluminescence rate. The light-emitting reaction in bacteria involves the oxidation of reduced flavin mononucleotide $\left(\mathrm{FMNH}_{2}\right)$ and a long chain fatty aldehyde with the emission of blue-green light [21, 22]. In both marine and terrestrial bioluminescent bacteria, a five-gene operon (luxCDABE) encodes the luciferase and biosynthetic enzymes (for the synthesis of the aldehyde substrate) necessary for light production. $\operatorname{lux} A$ and $\operatorname{lu} x B$ genes encode the $\alpha$ and $\beta$ subunits of the luciferase, and $\operatorname{lux} C, \operatorname{lux} D$ and luxE encode proteins for aldehyde production [23]. Although a number of additional lux genes in bioluminescent bacteria have been identified, only luxCDABE are essential for the biosynthetic production of light [21, 24].

Nearly 2 decades ago, the isolation of the genes responsible for bioluminescence in bacteria and the ability to transfer these genes into prokaryotic and eukaryotic organisms have greatly extended the capacity and potential uses of bacterial bioluminescence [21]. Amongst the applications of these recombinant bacteria, the clinical [20, 25-28], environmental [29-33] and biotechnology research [34, 35] are the most promising ones. In the clinical studies, this methodology is applied to laboratory animal models inoculated with genetically engineered bioluminescent bacteria in order to assess in vivo and in real time the progress of infectious diseases by optical detection through sensitive imaging cameras [18, 19, 26, 27, 36, 37]. The light output from these bioluminescent bacteria is a highly sensitive reporter of their metabolic activity [20, 38]. Furthermore, in experimental systems in which a strong correlation between bioluminescence and viable counts can be demonstrated, measurement of bioluminescence offers a rapid and alternative method for monitoring bacterial viability [20,39]. Light output is noncumulative, reflecting actual metabolic rate, and can be measured directly, continuously and nondestructively in high-throughput screening or continuousculture models [40]. Thus, the transformation of pathogenic bacteria into indicator bioluminescent strains allows using a rapid, sensitive and cost-effective methodology to evaluate the efficiency of PI [17, 18, 40-42].

In this study, we proposed to develop a rapid method to assess the antibacterial effect of meso-substituted porphyrins based on the metabolic activity of recombinant bioluminescent Escherichia coli (E. coli) under artificial and solar irradiation. As E. coli is an indicator of faecal pollution and is used to evaluate the quality of drinking, recreational and residual waters, it can be considered an adequate bacterium model to test the applicability of the bioluminescent method. Moreover, E. coli is a Gram-negative bacterium and it is much more resistant to photoinactivation than Gram-positive bacteria [9, 11, 43] and consequently when E. coli cells are inactivated, it is likely that other vegetative cells of Gram-positive bacteria are also inactivated [14, 44].

As far as we know, the use of bioluminescent bacteria with the purpose to monitor the antibacterial activity of porphyrins under environmental conditions has not yet been reported.

\section{Materials and methods}

\section{Photosensitizers}

The photosensitizers 5,10,15,20-tetrakis(1-methylpyridinium-4-yl)porphyrin tetra-iodide (Tetra-Py $\left.{ }^{+}-\mathrm{Me}\right)$, 5-(pentafluorophenyl)-10,15,20-tris(1-methylpyridinium-4-yl)porphyrin tri-iodide (Tri-Py $\left.{ }^{+}-\mathrm{Me}-\mathrm{PF}\right)$ and 5-(4-methoxycarbonyl10,15,20-tris (1-methylpyridinium-4-yl)porphyrin tri-iodide (Tri-Py ${ }^{+}-\mathrm{Me}-\mathrm{CO}_{2} \mathrm{Me}$ ) (Fig. 1) used in this work were prepared in two steps according to the literature [45, 46]. First, the neutral porphyrins were obtained from the Rothemund and crossed Rothemund reactions using pyrrole and the adequate aldehydes (pyridine-4-carbaldehyde and pentafluorobenzaldehyde or methyl 4-formylbenzoate) at reflux in acetic acid and nitrobenzene $[45,46]$. These reagents were 
Fig. 1 Structure of the three porphyrin derivatives used for the photoinactivation of bioluminescent $E$. coli

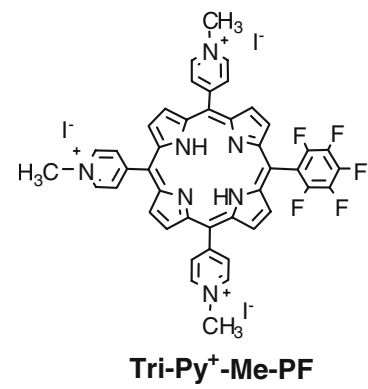

purchased from Sigma-Aldrich (Madrid, Spain). After purification of the resulting porphyrins by column chromatography (silica), their pyridyl groups were quaternized by reaction with methyl iodide. The cationic porphyrins were purified by crystallization from chloroform/methanol/petroleum ether and their purities were confirmed by thin layer chromatography and by ${ }^{1} \mathrm{H}$ NMR spectroscopy. The spectroscopic date was in accordance with the literature $[45,46]$. Stock solutions $(500 \mu \mathrm{M})$ of each porphyrin in dimethyl sulfoxide were prepared by dissolving the adequate amount of the desired porphyrin in a known volume. The absorption spectral features of the PS were the following: [porphyrin] $\lambda_{\max } \mathrm{nm}(\log \varepsilon)$; [Tetra-Py $\left.{ }^{+}-\mathrm{Me}\right]$ in DMSO 425 (5.43), 516 (4.29), 549 (3.77), 588 (3.84), 642 (3.30); [Tri$\left.\mathrm{Py}^{+}-\mathrm{Me}-\mathrm{PF}\right]$ in DMSO 422 (5.48), 485 (3.85), 513 (4.30), 545 (3.70), 640 (3.14); [Tri-Py ${ }^{+}-\mathrm{Me}-\mathrm{CO}_{2} \mathrm{Me}$ ] in $\mathrm{H}_{2} \mathrm{O} 420$ (5.54), 518 (4.12), 556 (3.74), 583 (3.78), 640 (3.27).

Bacterial strain, plasmid constructs and E. coli transformation

In this study, two plasmids (pHK724 and pHK555) were inserted into E. coli Top10 (Invitrogen, USA). These plasmids contain the lux operon from the bioluminescent marine bacterium Vibrio fischeri, required to produce light. The plasmid pHK724 contains a ColE1 replicon, an ampicillin resistance marker and luxR gene whose gene product is a transcription regulatory protein. The plasmid pHK555 contains a P15A replicon, a chloramphenicol resistance marker and a functional luxCDABE operon. The luxR gene of pHK555 is inactive because of the insertion of phage DNA. When pHK724 is inserted into E. coli containing pHK555, the resultant colonies grow on selective media and are bioluminescent $[47,48]$.

Chemically competent cells of $E$. coli Top 10 with plasmid pHK555 were prepared in the laboratory, and were further transformed with plasmid pHK724, as described earlier [49], resulting in a bioluminescent strain.

\section{Bacterial growth conditions}

Bioluminescent $E$. coli were grown on Luria Bertani agar (LB, Merck) supplemented with $50 \mathrm{mg} \mathrm{mL}^{-1}$ of ampicillin
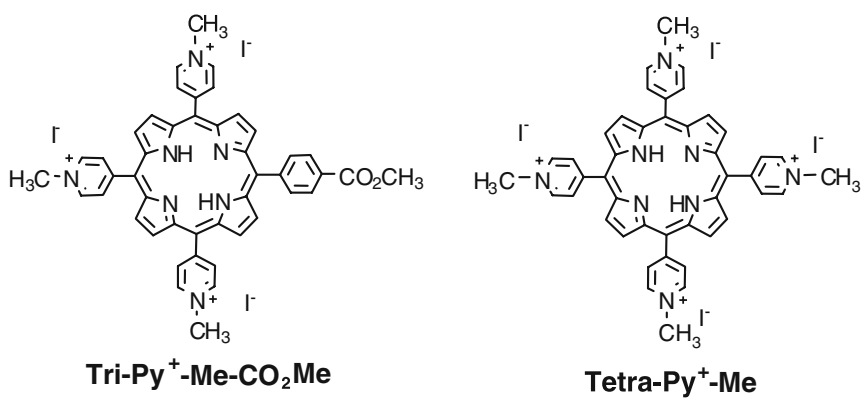

(Amp) and with $34 \mathrm{mg} \mathrm{mL}^{-1}$ of chloramphenicol (Cm). A stock culture was stored at $-80{ }^{\circ} \mathrm{C}$ in $10 \%$ glycerol. Before each PI assay, one colony of bioluminescent bacteria was aseptically inoculated into $30 \mathrm{~mL}$ of triptic soy broth (TSB, Merck) supplemented with both antibiotics (150 $\mu \mathrm{L} \mathrm{Amp/}$ $100 \mathrm{~mL}$ TSB and $60 \mu \mathrm{L} \mathrm{Cm} / 100 \mathrm{~mL}$ TSB) and were grown for one day, at room temperature, at $100 \mathrm{rpm}$ stirring. Then an aliquot of this culture was subcultured in $30 \mathrm{~mL}$ of fresh TSB with both antibiotics and was grown overnight, at room temperature, at $100 \mathrm{rpm}$ stirring, to reach stationary growth phase $\left(\mathrm{OD}_{600} \approx 1.3\right)$.

\section{Bioluminescence versus $\mathrm{CFU}$ of an overnight culture}

To assess the correlation between the colony-forming units (CFU) number and the bioluminescent signal of our indicator strain, two assays were carried out with and without porphyrin, in dark conditions. An overnight culture of bio-

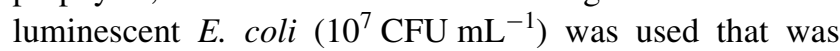
serially diluted $\left(10^{-1}-10^{-7}\right)$ in fresh phosphate buffered saline (PBS), $\mathrm{pH}$ 7.4. The non-diluted $\left(10^{\circ}\right)$ and diluted aliquots were read on a luminometer (TD-20/20 Luminometer, Turner Designs, Inc., USA) and simultaneously $1 \mathrm{~mL}$ of each dilution was pour plated in TSA medium. When the porphyrin $(5 \mu \mathrm{M})$ was added, a dark incubation was performed during $4 \mathrm{~h}$ at $25^{\circ} \mathrm{C}$ under stirring, before serially dilution and plating. Both experiments were done in duplicate and the results were averaged.

\section{Photosensitization procedure}

\section{Experimental setup}

Bacterial cultures grown overnight were tenfold diluted in PBS to a final concentration of $10^{6} \mathrm{CFU} \mathrm{\textrm {mL } ^ { - 1 }}$. This bacterial suspension was equally distributed in $100 \mathrm{~mL}$ sterilized and acid-washed glass beakers. Then, appropriate quantities of the three porphyrins under study were added to achieve final concentrations of $0.5,1.0$ and $5.0 \mu \mathrm{M}$ (total volume was $10 \mathrm{~mL}$ per beaker). The samples were protected from light with aluminium foil and incubated for $10 \mathrm{~min}$ under $100 \mathrm{rpm}$ stirring, at $25-30^{\circ} \mathrm{C}$, to promote the 
porphyrin binding to $E$. coli cells. Light and dark controls were carried out during the experiments. In the light control no porphyrin was added, but the beaker was exposed to the same irradiation protocol. In the dark control, the photosensitizer at the highest concentration $(5.0 \mu \mathrm{M})$ was added to the beaker and it was covered with aluminium foil.

Irradiation conditions

Following the pre-irradiation incubation period, the samples were exposed to two different light sources, until 270 min, under $100 \mathrm{rpm}$ stirring.

In laboratorial experiments with artificial light, white light (PAR radiation, 13 OSRAM 21 lamps of $18 \mathrm{~W}$ each, $380-700 \mathrm{~nm}$ ) was used with a fluence rate of $40 \mathrm{~W} \mathrm{~m}^{-2}$ (measured with a radiometer LI-COR Model LI-250). Samples were placed on a tray with clamps and the bottom of the tray was covered with water in order to maintain the samples at constant temperature $\left(25^{\circ} \mathrm{C}\right)$, as bioluminescent $V$. fischeri lux genes, emit light preferentially at temperatures below $30{ }^{\circ} \mathrm{C}[50]$.

The experiments with solar irradiation were carried out outside the laboratory. Samples were exposed to solar PAR light on sunny summer days, in the Littoral Centre of Portugal, where the averaged PAR light fluence rate was $620 \mathrm{~W} \mathrm{~m}^{-2}$ (measured with a radiometer LI-COR Model LI-250). To filter the ultraviolet radiation, samples were covered with a glass petri plate. Only the PAR radiation of the solar spectrum was used in order to avoid ultraviolet inactivation of the bacteria and thus to allow comparing of these results with those obtained with artificial light. Samples were also placed on a tray with clamps and the bottom was covered with water. Water temperature was monitored and maintained at $25^{\circ} \mathrm{C}$.

\section{Bioluminescence monitoring}

In both irradiation experiments, aliquots of treated and control samples were collected at time 0 and after 15, 30, 60, 90, 180 and 270 min of light exposure and the bioluminescence was measured in the luminometer.

\section{Statistical analysis}

All experiments for the three porphyrins were done in duplicate. Statistical analysis was performed by using SPSS (SPSS 15.0 for Windows, SPSS Inc., USA). Normal distributions were assessed by the Kolmogorov-Smirnov test. The significance of both light conditions and porphyrin derivatives on bacterial inactivation was assessed by two-way univariate analysis of variance (ANOVA) model with the Bonferroni post hoc test. A value of $P<0.05$ was considered significant.

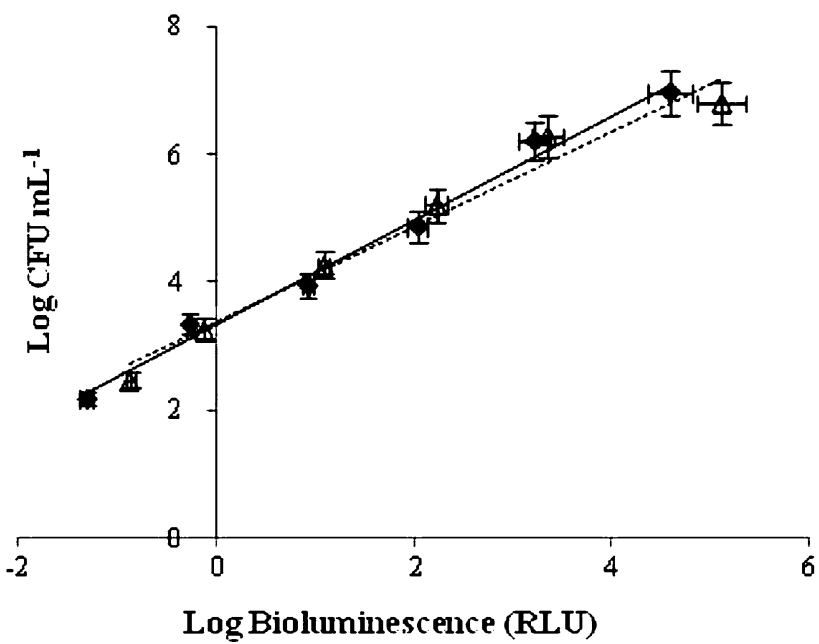

Fig. 2 Relationship between bioluminescence and viable counts of

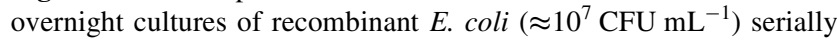
diluted in PBS. Bioluminescence is expressed in relative light units (RLU) and viable counts in CFU $\mathrm{mL}^{-1}$. The values are expressed as the means of two independent experiments; error bars indicate the standard deviation. (filled diamond E. coli suspension in the absence of PS, open triangle E. coli suspension with $5.0 \mu \mathrm{M}$ of $\mathrm{Tri}^{-} \mathrm{Py}^{+}-\mathrm{Me}-\mathrm{PF}$ incubated $4 \mathrm{~h}$ in the dark at $25^{\circ} \mathrm{C}$ )

\section{Results}

Bioluminescence versus $\mathrm{CFU}$ of an overnight culture

The linear relationship between the bioluminescence and viable counts of a growing culture of recombinant $E$. coli is presented in Fig. 2. The bioluminescence results reflect the viable bacterial abundance.

\section{Artificial light experiments}

Comparing the bioluminescence values obtained in the experiments carried out under the artificial light conditions (Figs. 3a, 4a, 5a), a clear difference in the PI patterns of the three porphyrins is observed. For the lower concentrations used $(0.5$ and $1.0 \mu \mathrm{M})$, the tricationic porphyrins (Tri-Py ${ }^{+}-$ $\mathrm{Me}-\mathrm{PF}$ and Tri-Py $\left.{ }^{+}-\mathrm{Me}-\mathrm{CO}_{2} \mathrm{Me}\right)$ are more efficient than the tetracationic one (Tetra-Py $\left.{ }^{+} \mathrm{Me}\right) \quad(P<0.05$, ANOVA). They caused more than $4 \log$ decrease in bioluminescence (reaching the limits of detection) after $270 \mathrm{~min}$ of irradiation, while at these concentrations and after the same period, the tetracationic porphyrin $\left(\mathrm{Tetra}-\mathrm{Py}^{+}-\mathrm{Me}\right)$ shows only a 0.50 and a $0.65 \log$ decrease in bioluminescence (Fig. 5a). With $5.0 \mu \mathrm{M}$, the PI pattern is not significantly different amongst the three porphyrins $(P>0.05$, ANOVA) all causing decreases in the bioluminescence higher than $4.2 \log$. 

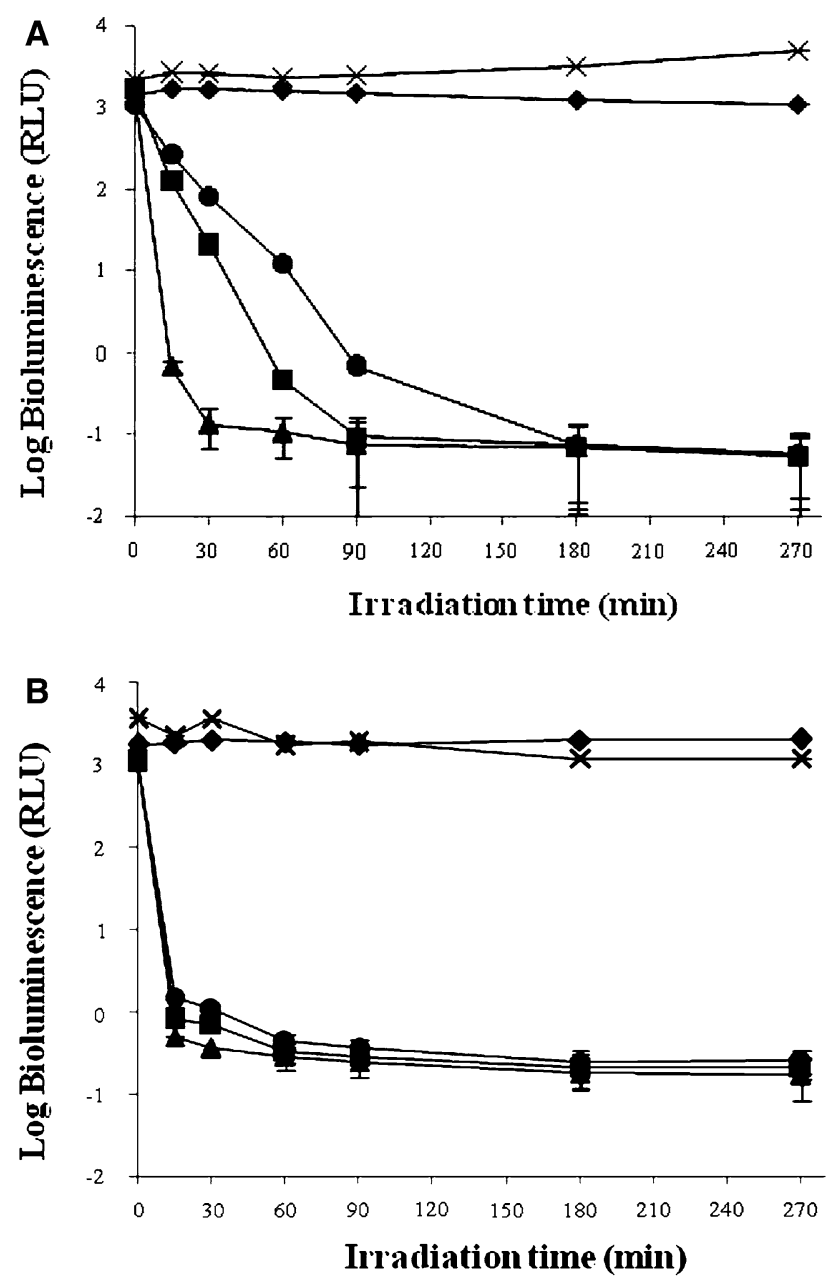

Fig. 3 Bioluminescence monitoring of E. coli treated with Tri-Py ${ }^{+}$ Me-PF. a Irradiation with artificial light $\left(40 \mathrm{~W} \mathrm{~m}^{-2}\right)$. b Irradiation with solar PAR light $\left(620 \mathrm{~W} \mathrm{~m}^{-2}\right)$. The values are expressed as the means of two independent experiments; error bars indicate the standard deviation; multisign light control, filled diamond dark control, filled circle $0.5 \mu \mathrm{M}$, filled square $1.0 \mu \mathrm{M}$, filled triangle $5.0 \mu \mathrm{M}$

\section{Solar light experiments}

The results of the experiments carried out under solar PAR light conditions $\left(\approx 620 \mathrm{~W} \mathrm{~m}^{-2}\right)$ show that the three porphyrins studied are able to cause a decrease in the bioluminescence signal to the limit of detection (more than $4 \mathrm{log}$ decrease) after $270 \mathrm{~min}$ of irradiation even with the lowest concentration tested (Figs. 3b, 4b, 5b). However, for the lower concentration values $(0.5$ and $1.0 \mu \mathrm{M})$, with Tri-Py+Me-PF the drop occurs earlier $(\approx 3 \log$ reduction of bioluminescence after $15 \mathrm{~min}$ ) than for the other porphyrins. After $15 \mathrm{~min}$ of irradiation, Tri-Py ${ }^{+}-\mathrm{Me}-\mathrm{CO}_{2} \mathrm{Me}$ caused bioluminescence reduction of $0.46 \log$ (both with 0.5 and $1.0 \mu \mathrm{M}$ ), while Tetra-Py ${ }^{+}$-Me caused $0.89 \log$ and $2.46 \log$ decrease with 0.5 and $1.0 \mu \mathrm{M}$, respectively. For the highest concentration, at short irradiation periods $(15 \mathrm{~min})$ the pho-
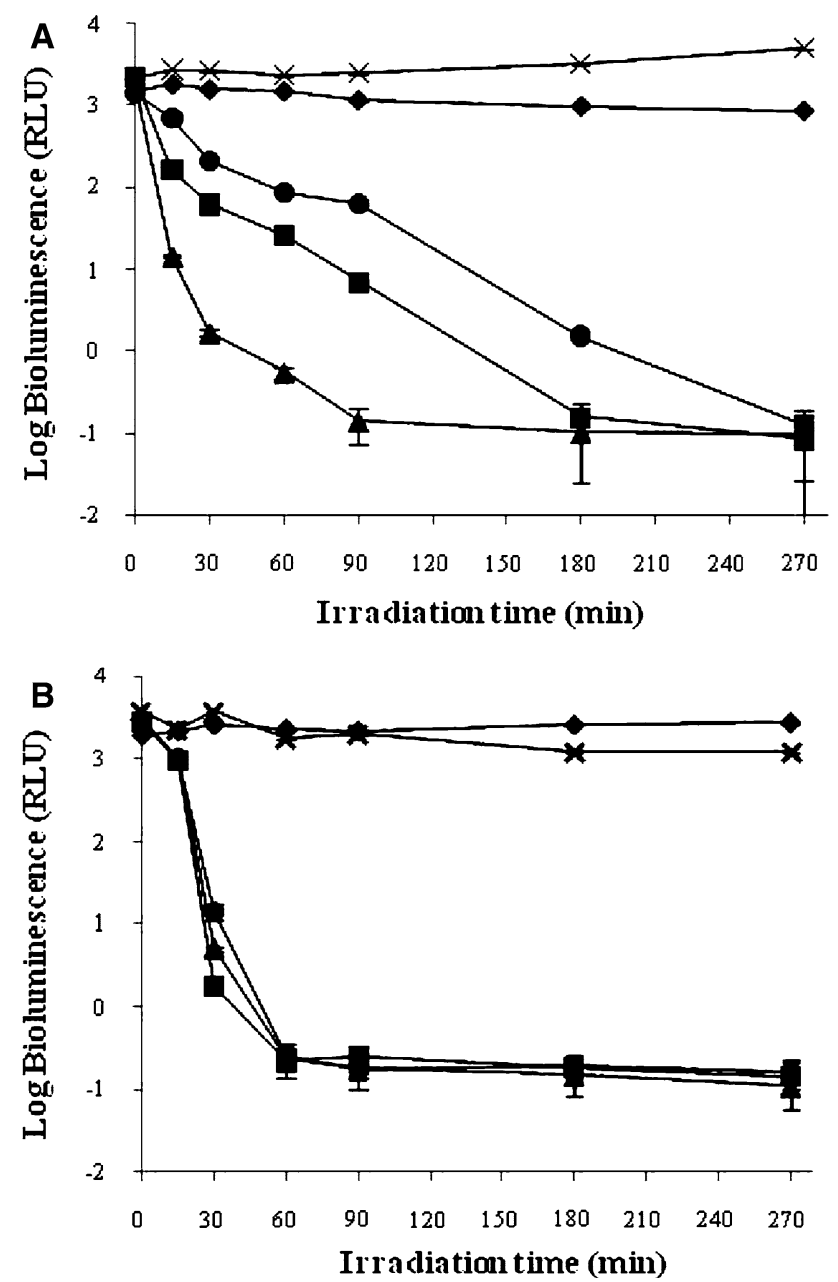

Fig. 4 Bioluminescence monitoring of E. coli treated with $\mathrm{Tri}_{-} \mathrm{Py}^{+}$ $\mathrm{Me}-\mathrm{CO}_{2} \mathrm{Me}$. a Irradiation with artificial light $\left(40 \mathrm{~W} \mathrm{~m}^{-2}\right)$. b Irradiation with solar PAR light $\left(620 \mathrm{~W} \mathrm{~m}^{-2}\right)$. The values are expressed as the means of two independent experiments; error bars indicate the standard deviation; multisign light control, filled diamond dark control, filled circle $0.5 \mu \mathrm{M}$, filled square $1.0 \mu \mathrm{M}$, filled triangle $5.0 \mu \mathrm{M}$

toinactivation with Tetra-Py ${ }^{+} \mathrm{Me}$ is slightly higher than that of Tri-Py ${ }^{+}-\mathrm{Me}-\mathrm{PF}$. However, after 90 min of irradiation, all the three porphyrins are similarly effective, reaching the detection limit.

\section{Control samples}

The results of the experiments carried out under artificial light conditions, show that the viability of the recombinant bioluminescent $E$. coli was not affected either by irradiation itself (light control) or by any of the PS tested (dark control) (Figs. 3a, 4a, 5a). The same was observed in the light and dark controls during solar light experiments. This clearly indicates that the cell viability reduction observed after irradiation of the treated samples is due to the photosensitization effect of the porphyrins. 

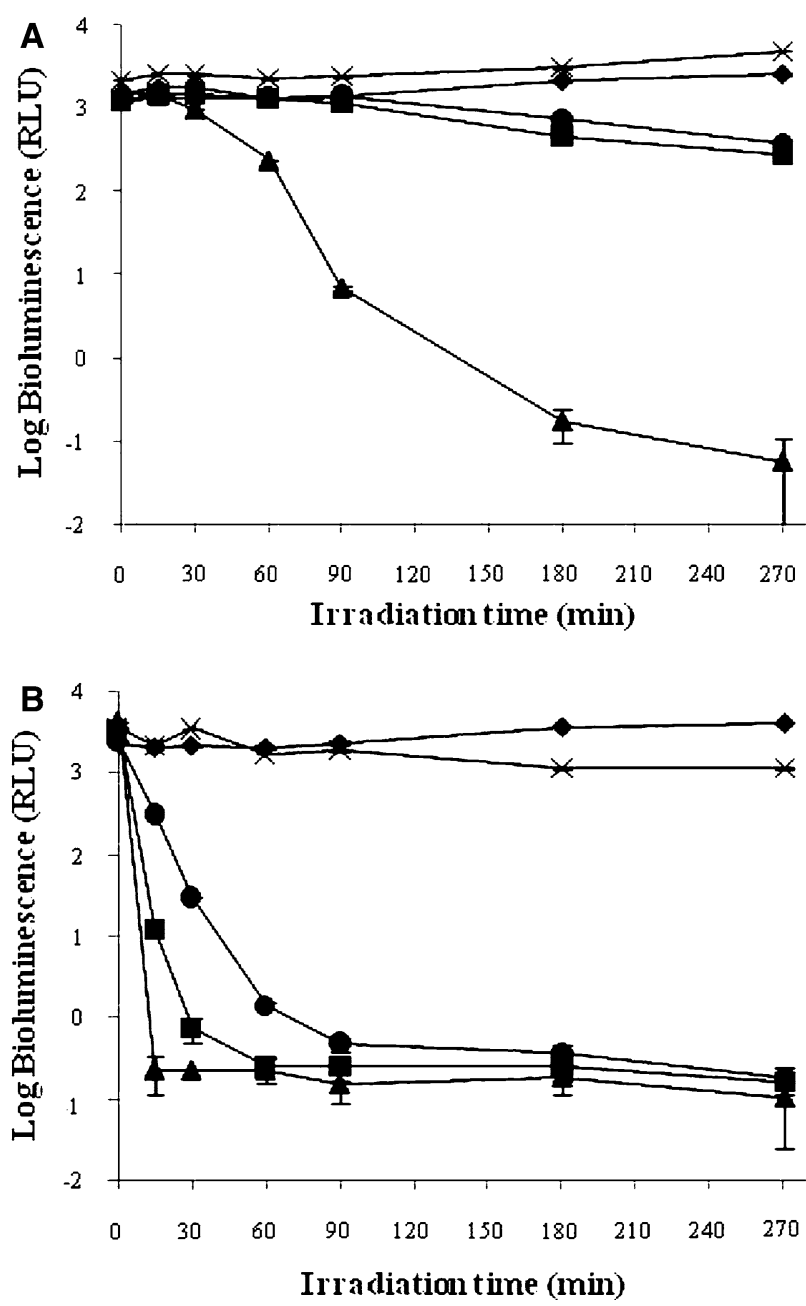

Fig. 5 Bioluminescence monitoring of E. coli treated with Tetra-Py+ Me. a Irradiation with artificial light $\left(40 \mathrm{~W} \mathrm{~m}^{-2}\right)$. b Irradiation with solar PAR light $\left(620 \mathrm{~W} \mathrm{~m}^{-2}\right)$. The values are expressed as the means of two independent experiments; error bars indicate the standard deviation; cross light control, filled diamond dark control, filled circle $0.5 \mu \mathrm{M}$, filled square $1.0 \mu \mathrm{M}$, filled triangle $5.0 \mu \mathrm{M}$

\section{Discussion}

Photodynamic antimicrobial therapy has been considered a promising alternative to treat skin lesions and dental infections $[8,51,52]$. The possibility to use this approach in the wastewater treatment, in order to avoid or reduce the environmental pollution and to promote the reuse of water for crop irrigation, for example, has led to the study of the efficiency of different PS on the inactivation of different microorganisms under different light fluencies [1-3, 6, 53]. The conventional methods used to test microbial PI in vitro require laborious techniques of plating, overnight incubation and the time-consuming counting of CFU. To this end, simpler, faster, cheaper and sensitive methods, as bioluminescence methods, are desirable for PI studies.

In the present study, we demonstrate that it is possible to rapidly photoinactivate bioluminescent $E$. coli with cationic meso-substituted porphyrin derivatives as PS. The bioluminescent indicator strain was obtained by transformation of an E. coli strain with the lux operon (luxCDABE) that emits light continuously without the addition of exogenous substrates [20]. The use of stable bioluminescent bacteria allows following the progress of the PI process with real time results. The bioluminescence was followed as a function of time to show that the transformed bacteria are stable light producers and the light production correlated with the growth of the bacteria (Fig. 2).

The relationship between cell viability and luminescence intensity in the presence and in the absence of the sensitizer is similar (Fig. 2), showing that the sensitizer is not toxic to the transformed bacterium and, consequently, does not affect the relationship between bacterial growth and luminescence. Moreover, the photoinactivation pattern obtained with the bioluminescence method is similar to that determined by the conventional plating technique for the E. coli strain with the Tri-Py ${ }^{+}-\mathrm{Me}-\mathrm{PF}$ sensitizer used in this assay [44].

The eventual metabolic stress introduced in the transformed bacterium during the plasmid insertion does not seem to affect the photoinactivation kinetics. The viability of bioluminescent strain is not affected by the porphyrin after $4 \mathrm{~h}$ of incubation in the dark (dark control in Figs. 3, 4,5 ) or by light irradiation (light control in Figs. 3, 4, 5). The bioluminescent strain is only affected by irradiation in the presence of the sensitizer (test samples in Figs. 3,4, 5), indicating that the decrease in bacterial viability is due to the photoinactivation process and not due to any kind of metabolic stress related to the plasmid insertion.

The experiments carried out with artificial light, with a fluence rate of $40 \mathrm{~W} \mathrm{~m}^{-2}$, show that the three porphyrins used are efficient PS against bioluminescent $E$. coli, causing a reduction on light signal to the limit of detection of the luminometer. The differences between the three porphyrins are more noticeable at lower concentrations of PI, since the PI by tricationic porphyrins is significantly higher than that by tetracationic porphyrin. At $5.0 \mu \mathrm{M}$ the differences are still observed for short irradiation periods but after $270 \mathrm{~min}$ of irradiation, all porphyrins show equal effectiveness.

Under solar irradiation with a fluence rate of $\approx 620 \mathrm{~W} \mathrm{~m}^{-2}$, Tri-Py ${ }^{+}-\mathrm{Me}-\mathrm{PF}$ is more effective than Tetra$\mathrm{Py}^{+}-\mathrm{Me}$ and $\mathrm{Tri}-\mathrm{Py}{ }^{+}-\mathrm{Me}-\mathrm{CO}_{2} \mathrm{Me}$ for low concentrations. With this porphyrin the PI is much faster (more than a $3 \mathrm{log}$ decrease after only $15 \mathrm{~min}$ of irradiation). At $5.0 \mu \mathrm{M}$, at lower irradiation periods, the Tetra-Py+ ${ }^{+} \mathrm{Me}$ is the more effective PS. As expected, when solar light is used the PI occurs faster due to the higher light fluence rate. 
This study shows that the PI of bioluminescent $E$. coli is achieved with both light fluences of 40 and $\approx 620 \mathrm{~W} \mathrm{~m}^{-2}$. It is worth to refer that the results obtained in this study for artificial light $\left(40 \mathrm{~W} \mathrm{~m}^{-2}\right)$ are in agreement with the PI patterns previously obtained for these PS where the conventional method of CFU count was carried out and a non-transformed E. coli stain was used [44]. The major difference is that, in the present study, the effect of the photosensitizers is observed immediately after the irradiation just by measuring bioluminescence of the test cell suspension. Since it does not require expensive equipment or materials, it can be used as a rapid method for monitoring PI experiments. For this reason, it can be concluded that the bacterial bioluminescence method is a sensitive, simple and cost-effective real time approach,

The complete inactivation of Gram (-) bacteria (to the limit of detection) with solar radiation shows that, using the adequate PS, the photodynamic antimicrobial therapy can be used for environmental applications, namely for the disinfection of wastewater under natural irradiation conditions. In order to make this method an inexpensive, easily applicable and an environmental-friendly technology to remove sewage bacteria from wastewater, the recovery and reutilization of these porphyrins is required. For that, their immobilization on solid supports is already being tested in our laboratory.

Acknowledgments We are grateful to Professor James Slock (King's College, EUA) for kindly providing E.coli strain with plasmid pHK555 and also plasmid pHK724. Thanks are due to the University of Aveiro, Fundação para a Ciência e a Tecnologia (FCT) and FEDER for funding the Organic Chemistry Research Unit (QOPNA) and the project POCI/CTM/58183/2004. To CESAM (Centro de Estudos do Ambiente e do Mar) for funding the Microbiology Research Group. C. M. B. Carvalho and J. P. Tomé are also grateful to FCT for their grants.

\section{References}

1. Jemli M, Alouini Z, Sabbahi S, Gueddari M (2002) Destruction of fecal bacteria in wastewater by three photosensitizers. J Environ Monit 4(4):511-516

2. Alouini Z, Jemli M (2001) Destruction of helminth eggs by photosensitized porphyrin. J Environ Monit 3(5):548-551

3. Bonnett R, Krysteva MA, Lalov IG, Artarsky SV (2006) Water disinfection using photosensitizers immobilized on chitosan. Water Res 40(6):1269-1275

4. Wainwright M (1998) Photodynamic antimicrobial chemotherapy (PACT). J Antimicrob Chemother 42(1):13-28

5. DeRosa M, Crutchley R (2002) Photosensitized singlet oxygen and its applications. Coord Chem Rev (233-234):351-371

6. Carvalho CMB, Gomes ATPC, Fernandes SCD, Prata ACB, Almeida MA, Cunha MA, Tomé JPC, Faustino MAF, Neves MGPMS, Tomé AC, Cavaleiro JAS, Lin Z, Rainho JP, Rocha J (2007) Photoinactivation of bacteria in wastewater by porphyrins: bacterial $\beta$-galactosidase activity and leucine-uptake as methods to monitor the process. J Photochem Photobiol B 88(2-3):112-118

7. Jiménez-Hernández ME, Manjón F, Garcia-Fresnadillo D, Orellana G (2005) Solar water disinfection by singlet oxygen photogenerated with polymer-supported Ru(II) sensitizers. Solar Energy 80:1382-1387

8. Jori G, Fabris C, Soncin M, Ferro S, Coppellotti O, Dei D, Fantetti L, Chiti G, Roncucci G (2006) Photodynamic therapy in the treatment of microbial infections: basic principles and perspective applications. Lasers Surg Med 38(5):468-481

9. Banfi S, Caruso E, Buccafurni L, Battini V, Zazzaron S, Barbieri P, Orlandi V (2006) Antibacterial activity of tetraaryl-porphyrin photosensitizers: an in vitro study on Gram negative and Gram positive bacteria. J Photochem Photobiol B 85(1):28-38

10. Caminos DA, Spesia MB, Durantini EN (2005) Photodynamic inactivation of Escherichia coli by novel meso-substituted porphyrins by 4-(3- $N, N, N$-trimethylammoniumpropoxy)phenyl and 4-(trifluoromethyl)phenyl groups. Photochem Photobiol Sci 5(1):56-65

11. Lazzeri D, Rovera M, Pascual L, Durantini EN (2004) Photodynamic studies and photoinactivation of Escherichia coli using meso-substituted cationic porphyrin derivatives with asymmetric charge distribution. Photochem Photobiol 80(2):286-293

12. Merchat M, Spikes JD, Bertoloni G, Jori G (1996) Studies on the mechanism of bacteria photosensitization by meso-substituted cationic porphyrins. J Photochem Photobiol B 35(3):149-157

13. Merchat M, Bertolini G, Giacomini P, Villanueva A, Jori G (1996) Meso-substituted cationic porphyrins as efficient photosensitizers of gram-positive and gram-negative bacteria. J Photochem Photobiol B 32(3):153-157

14. Ashkenazi H, Nitzan Y, Gal D (2003) Photodynamic effects of antioxidant substituted porphyrin photosensitizers on Gram-positive and -negative bacteria. Photochem Photobiol 77(2):186-191

15. Milanesio M, Alvarez M, Silber J, Rivarola V, Durantini E (2003) Photodynamic activity of monocationic and non-charged methoxyphenylporphyrin derivatives in homogeneous and biological media. Photochem Photobiol Sci 2(9):926-933

16. Demidova T, Hamblin M (2005) Effect of cell-photosensitizer binding and cell density on microbial photoinactivation. Antimicrob Agents Chemother 49(6):2329-2335

17. Vesterlund S, Paltta J, Laukova A, Karp M, Ouwehand AC (2004) Rapid screening method for the detection of antimicrobial substances. J Microbiol Methods 57(1):23-31

18. Hamblin MR, O'Donnell DA, Murthy N, Contag CH, Hasan T (2002) Rapid control of wound infections by targeted photodynamic therapy monitored by in vivo bioluminescence imaging. Photochem Photobiol 75(1):51-57

19. Francis KP, Yu J, Bellinger-Kawahara C, Joh D, Hawkinson MJ, Xiao G, Purchio TF, Caparon MG, Lipsitch M, Contag PR (2001) Visualizing pneumococcal infections in the lungs of live mice using bioluminescent Streptococcus pneumoniae transformed with a novel gram-positive lux transposon. Infect Immun 69(5):3350-3358

20. Rocchetta HL, Boylan CJ, Foley JW, Iversen PW, LeTourneau DL, McMillian CL, Contag PR, Jenkins DE, Parr TR Jr (2001) Validation of a noninvasive, real-time imaging technology using bioluminescent Escherichia coli in the neutropenic mouse thigh model of Infection. Antimicrob Agents Chemother 45(1):129-137

21. Meighen EA (1993) Bacterial bioluminescence: organization, regulation, and application of the lux genes. FASEB J 7(11):1016-1022

22. Rodriguez A, Nabi I, Meighen E (1985) ATP turnover by the fatty acid reductase complex of Photobacterium phosphoreum. Can J Biochem Cell Biol (63):1106-1111

23. Meighen EA (1991) Molecular biology of bacterial bioluminescence. Microbiol Mol Biol Rev 55(1):123-142

24. Meighen EA (1994) Genetics of bacterial bioluminescence. Ann Rev Genet 28(1):117-139

25. Contag CH, Jenkins D, Contag PR, Negrin RS (2000) Use of reporter genes for optical measurements of neoplastic disease in vivo. Neoplasia 2:41-52 
26. Demidova T, Gad F, Zahra T, Francis K, Hamblin M (2005) Monitoring photodynamic therapy of localized infections by bioluminescence imaging of genetically engineered bacteria. J Photochem Photobiol B 81(1):25

27. Doyle TC, Nawotka KA, Kawahara CB, Francis KP, Contag PR (2006) Visualizing fungal infections in living mice using bioluminescent pathogenic Candida albicans strains transformed with the firefly luciferase gene. Microb Pathog 40(2):82-90

28. Jawhara S, Mordon S (2004) In vivo imaging of bioluminescent Escherichia coli in a cutaneous wound infection model for evaluation of an antibiotic therapy. Antimicrob Agents Chemother 48(9):3436-3441

29. Burlage RS, Sayler GS, Larimer F (1990) Monitoring of naphthalene catabolism by bioluminescence with nah-lux transcriptional fusions. J Bacteriol 172(9):4749-4757

30. Grande R, Pietro SD, Campli ED, Bartolomeo SD, Filareto B, Cellini L (2007) Bio-toxicological assays to test water and sediment quality. J Environ Sci Health A 42(1):33-38

31. Johnson B (2005) Microtox ${ }^{\circledR}$ acute toxicity test. Small-scale freshwater toxicity investigations, Springer Netherlands, pp 69-105

32. Ptitsyn LR, Horneck G, Komova O, Kozubek S, Krasavin EA, Bonev M, Rettberg P (1997) A biosensor for environmental genotoxin screening based on an SOS lux assay in recombinant Escherichia coli cells. Appl Environ Microbiol 63(11):4377-4384

33. Verschaeve L, Van Gompel J, Thilemans L, Regniers L, Vanparys P, van der Lelie D (1999) VITOTOX ${ }^{\circledR}$ bacterial genotoxicity and toxicity test for the rapid screening of chemicals. Environ Mol Mutagen 33(3):240-248

34. Maoz A, Mayr R, Bresolin G, Neuhaus K, Francis KP, Scherer S (2002) Sensitive in situ monitoring of a recombinant bioluminescent Yersinia enterocolitica reporter mutant in real time on camembert cheese. Appl Environ Microbiol 68(11):5737-5740

35. Kadurugamuwa JL, Sin L, Albert E, Yu J, Francis K, DeBoer M, Rubin M, Bellinger-Kawahara C, Parr TR Jr, Contag PR (2003) Direct Continuous Method for Monitoring Biofilm Infection in a Mouse Model. Infect Immun 71(2):882-890

36. Contag C, Contag P, Mullins J, Spilman S, Stevenson D, Benaron D (1995) Photonic detection of bacterial pathogens in living hosts. Mol Microbiol 4(18):593-603

37. Francis KP, Joh D, Bellinger-Kawahara C, Hawkinson MJ, Purchio TF, Contag PR (2000) Monitoring bioluminescent Staphylococcus aureus infections in living mice using a novel luxABCDE construct. Infect Immun 68(6):3594-3600

38. Salisbury Salisbury V, Pfoestl A, Wiesinger-Mayr H, Lewis R, Bowker KE, MacGowan AP (1999) Use of a clinical Escherichia coli isolate expressing lux genes to study the antimicrobial pharmacodynamics of moxifloxacin. $\mathrm{J}$ Antimicrob Chemother 43(6):829-832
39. Marincs F (2000) On-line monitoring of growth of Escherichia coli in batch cultures by bioluminescence. Appl Microbiol Biotechnol 53(5):536-541

40. Beard S, Salisbury V, Lewis R, Sharpe J, MacGowan A (2002) Expression of lux genes in a clinical isolate of Streptococcus pneumoniae: using bioluminescence to monitor gemifloxacin activity. Antimicrob Agents Chemother 46(2):538-542

41. Jawhara S, Mordon S (2006) Monitoring of bactericidal action of laser by in vivo imaging of bioluminescent $E$. coli in a cutaneous wound infection. Lasers Med Sci 21(3):153-159

42. Simon L, Fremaux C, Cenatiempo Y, Berjeaud JM (2001) Luminescent method for the detection of antibacterial activities. Appl Microbiol Biotechnol V57(5):757-763

43. Spesia MB, Lazzeri D, Pascual L, Rovera M, Durantini EN (2005) Photoinactivation of Escherichia coli using porphyrin derivatives with different number of cationic charges. FEMS Immunol Med Microbiol 44(3):289-295

44. Alves E, Almeida A, Cunha Â, Carvalho C, Faustino M, Tomé J, Neves M, Tomé A, Cavaleiro J (2007) Effect of the porphyrin charge in the inactivation of enteric bacteria. Faro, Portugal pp 195

45. Sirish M, Chertkov V, Schneider H (2002) Porphyrin-based peptide receptors: synthesis and NMR analysis. Chem Eur J 8(5):1181-1188

46. Tomé JPC, Neves MGPMS, Tomé AC, Cavaleiro JAS, Soncin M, Magaraggia M, Ferro S, Jori G (2004) Synthesis and antibacterial activity of new poly-S-lysine-porphyrin conjugates. J Med Chem 47(26):6649-6652

47. Kaplan HB, Greenberg EP (1987) Overproduction and Purification of the luxR Gene Product: Transcriptional Activator of the Vibrio fischeri Luminescence System. PNAS 84(19):6639-6643

48. Slock J, VanRiet D, Kolibachuk D, Greenberg EP (1990) Critical regions of the Vibrio fischeri luxR protein defined by mutational analysis. J Bacteriol 172(7):3974-3979

49. Sambrook J, Fritsch E, Maniatis T (1989) Molecular cloning: a laboratory manual. Cold Spring Harbor Laboratory Press, New York

50. Hill P, Rees C, Winson M, Stewart G (1993) The application of lux genes. Biotechnol Appl Biochem (17):3-14

51. Maisch T, Szeimies R, Jori G, Abels C (2004) Antibacterial photodynamic therapy in dermatology. Photochem Photobiol Sci (3):907-917

52. Komerik N, Nakanishi H, MacRobert AJ, Henderson B, Speight $P$, Wilson M (2003) In vivo killing of Porphyromonas gingivalis by toluidine blue-mediated photosensitization in an animal model. Antimicrob Agents Chemother 47(3):932-940

53. Costa L, Alves E, Carvalho C, Tomé J, Faustino M, Neves M, Tomé A, Cavaleiro J, Cunha Â, Almeida A (2008) Sewage bacteriophage photoinactivation by cationic porphyrins: a study of charge effect. Photochem Photobiol Sci 7:415-422 